\title{
Mechanisms of pyrethroid resistance in Haematobia irritans (Muscidae) from Mato Grosso do Sul state, Brazil
}

Mecanismos de resistência da Haematobia irritans (Muscidae) a piretróides em Mato Grosso do Sul, Brasil

Antonio Thadeu Medeiros Barros ${ }^{1 *}$; Teresinha Tizu Sato Schumaker²; Wilson Werner Koller; Guilherme Marcondes Klafké; Thais Aguiar de Albuquerque²; Rodrigo Gonzalez ${ }^{2}$

${ }^{1}$ Embrapa Pantanal, Corumbá, MS, Brasil

${ }^{2}$ Departamento de Parasitologia, Instituto de Ciências Biomédicas - ICB, Universidade de Sáo Paulo - USP, São Paulo, SP, Brasil

${ }^{3}$ Embrapa Gado de Corte, Campo Grande, MS, Brasil

${ }^{4}$ Instituto de Pesquisas Veterinárias Desidério Finamor - Fepagro/IPVDF, Eldorado do Sul, RS, Brasil

Received December 6, 2012

Accepted February 5, 2013

\begin{abstract}
Horn fly resistance to pyrethroid insecticides occurs throughout Brazil, but knowledge about the involved mechanisms is still in an incipient stage. This survey was aimed to identify the mechanisms of horn fly resistance to cypermethrin in Mato Grosso do Sul state, Brazil. Impregnated filter paper bioassays using cypermethrin, synergized or not with piperonyl butoxide (PBO) and triphenyl phosphate (TPP), were conducted from March 2004 to June 2005 in horn fly populations $(\mathrm{n}=33)$ from all over the state. All populations were highly resistant to cypermethrin, with resistance factors (RF) ranging from 89.4 to 1,020.6. Polymerase chain reaction (PCR) assays to detect the knockdown resistance $(k d r)$ mutation also were performed in 16 samples. The $k d r$ mutation was found in $75 \%$ of the tested populations, mostly with relatively low frequencies $(<20 \%)$, and was absent in some highly resistant populations. Addition of TPP did not significantly reduce the $\mathrm{LC}_{50}$ in any population. However, $\mathrm{PBO}$ reduced $\mathrm{LC}_{50} \mathrm{~s}$ above 40 -fold in all tested populations, resulting in RFs $\leq 10$ in most cases. Horn fly resistance to cypermethrin is widespread in the state, being primarily caused by an enhanced activity of P 450 mono-oxygenases and secondarily by reduced target site sensitivity.
\end{abstract}

Keywords: Horn fly, insecticide resistance, metabolic resistance, $k d r$.

\section{Resumo}

Resistência da mosca-dos-chifres a inseticidas piretróides ocorre em todo o país, entretanto, o conhecimento sobre os mecanismos envolvidos é ainda incipiente. Este estudo objetivou identificar os mecanismos de resistência desta mosca à cipermetrina em Mato Grosso do Sul. Bioensaios utilizando papéis impregnados com cipermetrina, isoladamente ou sinergizada por butóxido de piperonila (PBO) ou trifenil fosfato (TPP), foram realizados de março/2004 a junho/2005 em 33 populaçóes. Todas as populaçóes apresentaram elevada resistência à cipermetrina, com fatores de resistência (FR) variando de 89,4 a 1.020,6. Ensaios de reação em cadeia da polimerase (PCR) visando a deteç̧ão de $k d r$ ("knockdown resistance") foram realizados em 16 amostras. A mutaçáo $k d r$ foi detectada em $75 \%$ das populaçóes, geralmente em baixas frequências (<20\%) e ausente em algumas populações resistentes. A adição de TPP não reduziu significativamente a $\mathrm{CL}_{50}$ em nenhuma população. Entretanto, o $\mathrm{PBO}$ reduziu em mais de 40 vezes a $\mathrm{CL}_{50}$ de todas as populaçóes testadas, resultando em FR $\leq 10$ na maioria dos casos. Resistência da mosca-dos-chifres à cipermetrina encontra-se disseminada no estado, sendo causada primariamente por um aumento da atividade de $\mathrm{P} 450$ mono-oxigenases e secundariamente pela redução da sensibilidade do sítio de ação do inseticida.

Palavras-chave: Mosca-dos-chifres, resistência a inseticidas, resistência metabólica, $k d$.

\footnotetext{
*Corresponding author: Antonio Thadeu Medeiros Barros

Embrapa Pantanal, Rua 21 de Setembro, 1880, Nossa Senhora de Fátima,

CP 109, CEP 79320-900, Corumbá, MS, Brasil

e-mail: thadeu.barros@embrapa.br
} 


\section{Introduction}

It took about a century for the horn fly, Haematobia irritans irritans, to cross the American continent after its introduction in the United States during the 1880's (SLINGERLAND, 1891) until it reached Southern Cone countries (VALÉRIO; GUIMARÃES, 1983; LUZURIAGA et al., 1991; CARBALLO; MARTÍNEZ, 1991).

Although resistance to several insecticide classes had been previously reported in U.S. (SPARKS et al., 1985), horn fly populations remained susceptible in Brazil until the mid 1990's, as shown by efficacy (GRISI; SCOTT, 1992; PEREIRA et al., 1994) and bioassay (SCOTT et al., 1994) studies with pyrethroid and organophosphate insecticides. However, continued reliance on commercial pyrethroid products for controlling cattle pests led to development of pyrethroid resistance in horn fly populations and became a major concern throughout the country (BARROS et al., 2012).

Insecticide resistance is an individual mutation-induced reduction in susceptibility to lethal drugs, which may become a population trait through selection by drug exposure, thus impairing the insect control. Individual horn fly resistance to pyrethroids may be phenotypically expressed by changes in penetration and metabolism of those compounds (SPARKS et al., 1990; SHEPPARD, 1995) as well as reduced target site sensitivity (knockdown resistance) (GUERRERO et al., 1997). Knockdown resistance $(k d r)$ and enhanced metabolic detoxification have been considered the major mechanisms involved in pyrethroid resistance (BULL et al., 1988; SPARKS et al. 1990; SHEPPARD, 1995).
The $k d r$ is already known in Brazilian pyrethroid-resistant horn fly populations (GUERRERO; BARROS, 2006; SABATINI et al., 2009), but little is known about its real importance and the role played by metabolic mechanisms.

This study reports a survey on susceptibility of horn flies to cypermethrin and the search for the mechanisms behind horn fly resistance to pyrethroids in the state of Mato Grosso do Sul, Brazil.

\section{Materials and Methods}

The field survey was conducted from March 2004 to June 2005 in the state of Mato Grosso do Sul (Figure 1), located in the Brazilian Mid-West, looking for mechanisms of pyrethroid resistance in horn fly populations. Horn fly field bioassays and sampling were conducted by Embrapa Pantanal and the molecular analyses of fly samples were performed at the University of São Paulo (USP).

\section{Field bioassays}

Previous selection of cattle ranches for conducting the insecticide bioassays was based on convenience and practical factors (ease of access, owner concurrence, suitable infrastructure, and fly availability), but was random regarding suspicion of insecticide resistance or any other particular situation. Ranchers were previously requested to keep a cattle herd untreated for at least two weeks before testing.

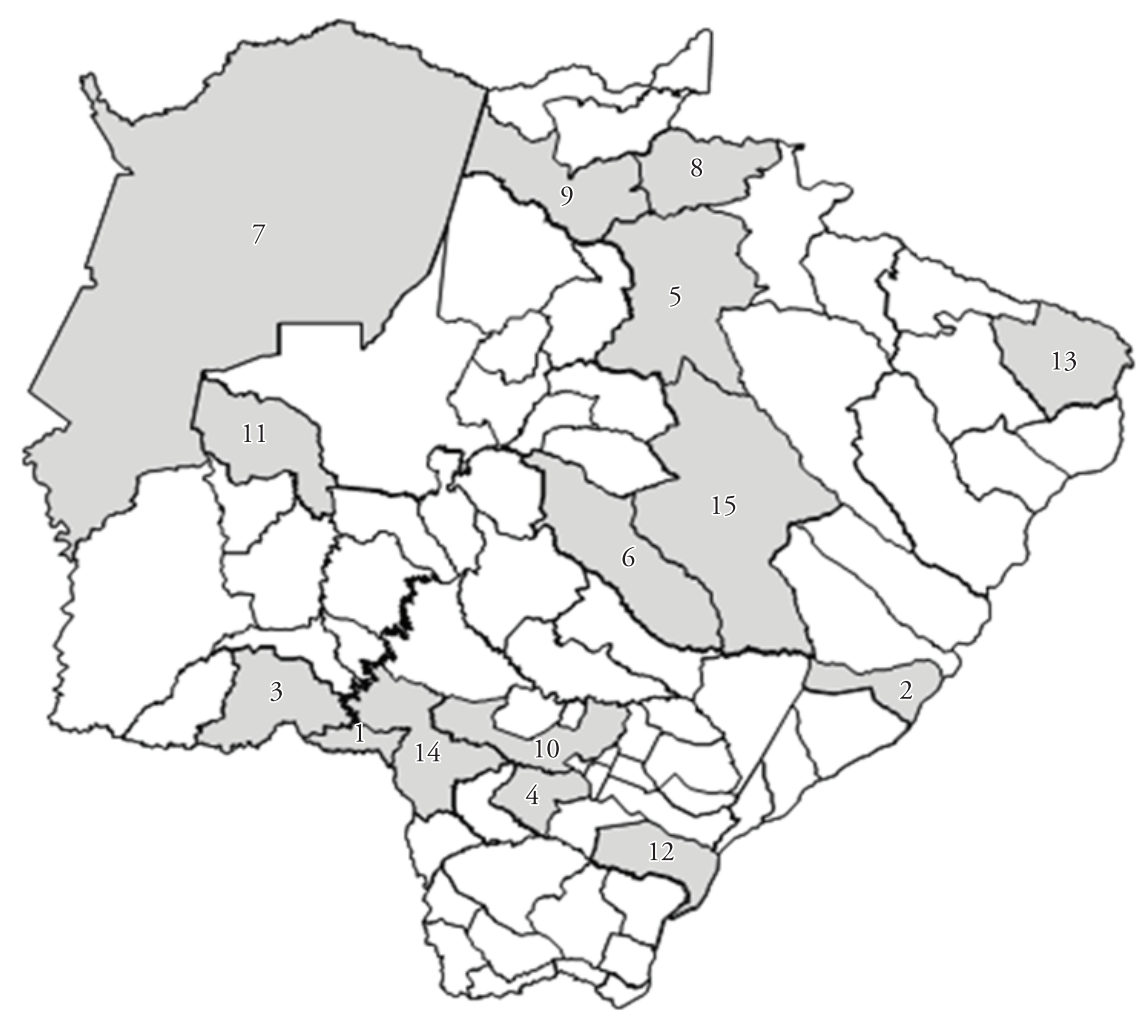

Municipality legend

1. Antônio Joāo

2. Bataguassu

3. Bela Vista

4. Caarapó

5. Camapuá

6. Campo Grande

7. Corumbá

8. Costa Rica

9. Coxim

10. Dourados

11. Miranda

12. Navirai

13. Paranaíba

14. Ponta Porá

15. Ribas do Rio Pardo

Figure 1. Geographic scope of the survey on horn fly susceptibility and resistance mechanisms to pyrethroids in the state of Mato Grosso do Sul, Brazil (2004-2005). 
Impregnated filter paper bioassays (SHEPPARD; HINKLE, 1987) were used to assess susceptibility of horn fly populations to technical grade cypermethrin (89.56\% purity) serially diluted in acetone (Merck P.A.). Cypermethrin kits contained three replicates of ten concentrations ranging from 1.6 to $819.2 \mu \mathrm{g} / \mathrm{cm}^{2}$, which allowed assessment of variable levels of susceptibility in the field. Control papers were treated with acetone only. Impregnated filter papers were kept in aluminum foil under refrigeration until they were placed in plastic Petri dishes (90 $\mathrm{mm}$ diameter) before the bioassay. Each treated paper was used in four bioassays (twice per side).

To investigate the involvement of metabolic mechanisms in resistance, bioassays with cypermethrin synergized with either 5\% piperonyl butoxide (PBO, 90\% purity, Sigma-Aldrich, USA) or $5 \%$ triphenyl phosphate (TPP, $+99 \%$ purity, Sigma-Aldrich, USA) were also performed at each site, depending on fly availability. After dilution in acetone, the synergist concentration (5\%) was kept constant along the insecticide concentrations. After preliminary field bioassays for adjusting insecticide concentration range in the kits, concentrations of cypermethrin-TPP were similar to cypermethrin alone $\left(1.6-819.2 \mu \mathrm{g} / \mathrm{cm}^{2}\right)$, while the concentration range of cypermethrin-PBO was much lower and varied from 0.1 to $3.2 \mu \mathrm{g} / \mathrm{cm}^{2}$. In each bioassay, the potential toxicity of synergists was evaluated by papers treated with the $5 \%$ synergist solution only.

Horn flies were collected from cattle with entomological hand nets and transferred to dishes immediately after an adequate number of flies had been collected. Early fly mortality was assessed immediately after dishes were loaded and dead flies were excluded if present. Actual fly susceptibility to the insecticide was evaluated by assessing fly mortality after a 2-hour exposure; flies unable to walk were considered dead. After insecticide kits were loaded, a sample of that population was transferred to a plastic vial with commercial ethanol for later molecular studies.

Pooled mortality data from the three replications were analyzed by probit analysis using POLO-PC (LEORA SOFTWARE, 1987) to obtain lethal concentration $\left(\mathrm{LC}_{50}\right)$ and respective fiducial limits for each field population. Bioassays with fly mortality $>10 \%$ in control dishes were not considered. The insecticide kits produced yearly were tested with a susceptible horn fly colony maintained at the USDA-ARS Knipling-Bushland US Livestock Insects Research Laboratory (Kerrville, TX, USA) to provide reference $\mathrm{LC}_{50}$. Resistance factors (RFs) were calculated by dividing $\mathrm{LC}_{50}$ from field populations by the $\mathrm{LC}_{50}$ from the susceptible colony. Differences in $\mathrm{LC}_{50}$ were assumed to be statistically significant when $95 \%$ fiducial limits did not overlap.

\section{Molecular analysis}

Polymerase chain reaction (PCR) was performed in horn flies from 16 populations sampled in 14 municipalities. Detection of the $k d r$ genotype mutation for each population followed the protocol of Guerrero et al. (1998). Alleles from 35 individuals were amplified per sampled population.

\section{Extraction of genomic $D N A$}

Genomic DNA was extracted according to Moreira-Ferro et al. (1998), with some modifications. The head of flies were individually homogenized in $50 \mu \mathrm{L}$ of lysis buffer $(100 \mathrm{mM}$ Tris- $\mathrm{HCl} \mathrm{pH} 7.5$;
$100 \mathrm{mM} \mathrm{NaCl} ; 100 \mathrm{mM}$ EDTA; 1\% SDS; $1 \mathrm{mg} / \mathrm{mL}$ proteinase K) and incubated for $1 \mathrm{~h}$ at $60^{\circ} \mathrm{C}$. The sample containing genomic DNA was subjected to extraction with an equal volume of phenol $(2 \times)$, phenol/chloroform (1×), and chloroform/isoamilic (1×). The DNA contained in the aqueous phase was precipitated by adding $100 \%$ ethanol and incubated (20 minutes) in ethanol with dry ice.

After centrifugation $\left(5\right.$ minutes, $\left.11,600 \mathrm{~g}, 4^{\circ} \mathrm{C}\right)$, the pellet was dissolved in $1 \mathrm{ml}$ of TE (10 mM Tris; $1 \mathrm{mM}$ EDTA, pH 8.0) containing $10 \mathrm{mg} / \mathrm{mL}$ RNAse. The DNA was again precipitated by adding $20 \%(\mathrm{v} / \mathrm{v})$ of $3 \mathrm{M}$ sodium acetate and $1 \mathrm{~mL}$ of isopropanol. Next, the suspension was maintained for 15 minutes at room temperature and then centrifuged ( 30 minutes, $11,600 \mathrm{~g}, 4^{\circ} \mathrm{C}$ ). The precipitate obtained was washed with $70 \%$ ethanol, dried in a vacuum centrifuge, and then dissolved in $20 \mu \mathrm{L}$ of bidistilled water.

\section{4. $K d r$ detection}

The $k d r$ gene was amplified from total genomic DNA according to Guerrero et al. (1998). The PCR was conducted with $25 \mathrm{ng}$ of genomic DNA, 20 pmol of each primer (FG-129, FG-138, and/or FG-130 or FG-134) (GUERRERO et al., 1998), 10 mM Tris (hydroxymethyl) aminomethane hydrochloride $\mathrm{pH} 8.3,50 \mathrm{mM} \mathrm{KCl}$, $0.05 \mathrm{mM}$ each dNTP, $3.5 \mathrm{mM} \mathrm{MgCl}_{2}$, and $0.1 \mu \mathrm{L}$ of $1: 1$ (vol:vol) mix of AmpliTaq DNA polymerase ( 5 units per microliter of stock solution (ss)) and TaqStart Antibody $(1.1 \mu \mathrm{L} / \mu \mathrm{L} s \mathrm{~s})$. PCR was conducted as follows: $96^{\circ} \mathrm{C}$ for 2 minutes, 35 cycles $\left(94^{\circ} \mathrm{C}\right.$ for 1 minute, $62^{\circ} \mathrm{C}$ for 1 minute, $72^{\circ} \mathrm{C}$ for 1 minute) and $72{ }^{\circ} \mathrm{C}$ for 7 minutes. The PCR product was visualized on $1.4 \%$ agarose gel stained with ethidium bromide after electrophoresis.

\section{Results and Discussion}

A total of 87 bioassays were conducted on 33 cattle ranches located in 15 municipalities from all ten microregions of the state (Table 1). High levels of resistance to cypermethrin were detected in all populations, with RF ranging from 89.4 to $1,020.6$ (Table 2). Except for one population, the RFs were above 100. All resistance levels were much higher than necessary to reduce efficacy of cypermethrin-based products for controlling horn flies (GUGLIELMONE et al., 1998). Therefore, failure of horn fly control was expected to occur in those ranches, as informed during visits.

Table 1. Survey on horn fly susceptibility and resistance mechanisms to pyrethroids in the state of Mato Grosso do Sul, Brazil (2004-2005).

\begin{tabular}{|c|c|c|}
\hline Mesoregions & Microregions & Municipalities \\
\hline \multirow{2}{*}{ Mid-North } & Alto Taquari & Camapuã, Coxim \\
\hline & Campo Grande & Campo Grande \\
\hline \multirow{4}{*}{ East } & Cassilândia & Costa Rica \\
\hline & Nova Andradina & Bataguassu \\
\hline & Paranaíba & Paranaíba \\
\hline & Três Lagoas & Ribas do Rio Pardo \\
\hline \multirow{2}{*}{ Pantanais } & Baixo Pantanal & Corumbá \\
\hline & Aquidauana & Miranda \\
\hline \multirow{2}{*}{ Southwest } & Bodoquena & Bela Vista, Ponta Porã \\
\hline & Dourados & $\begin{array}{l}\text { Antônio João, Caarapó, } \\
\text { Dourados, Naviraí }\end{array}$ \\
\hline
\end{tabular}




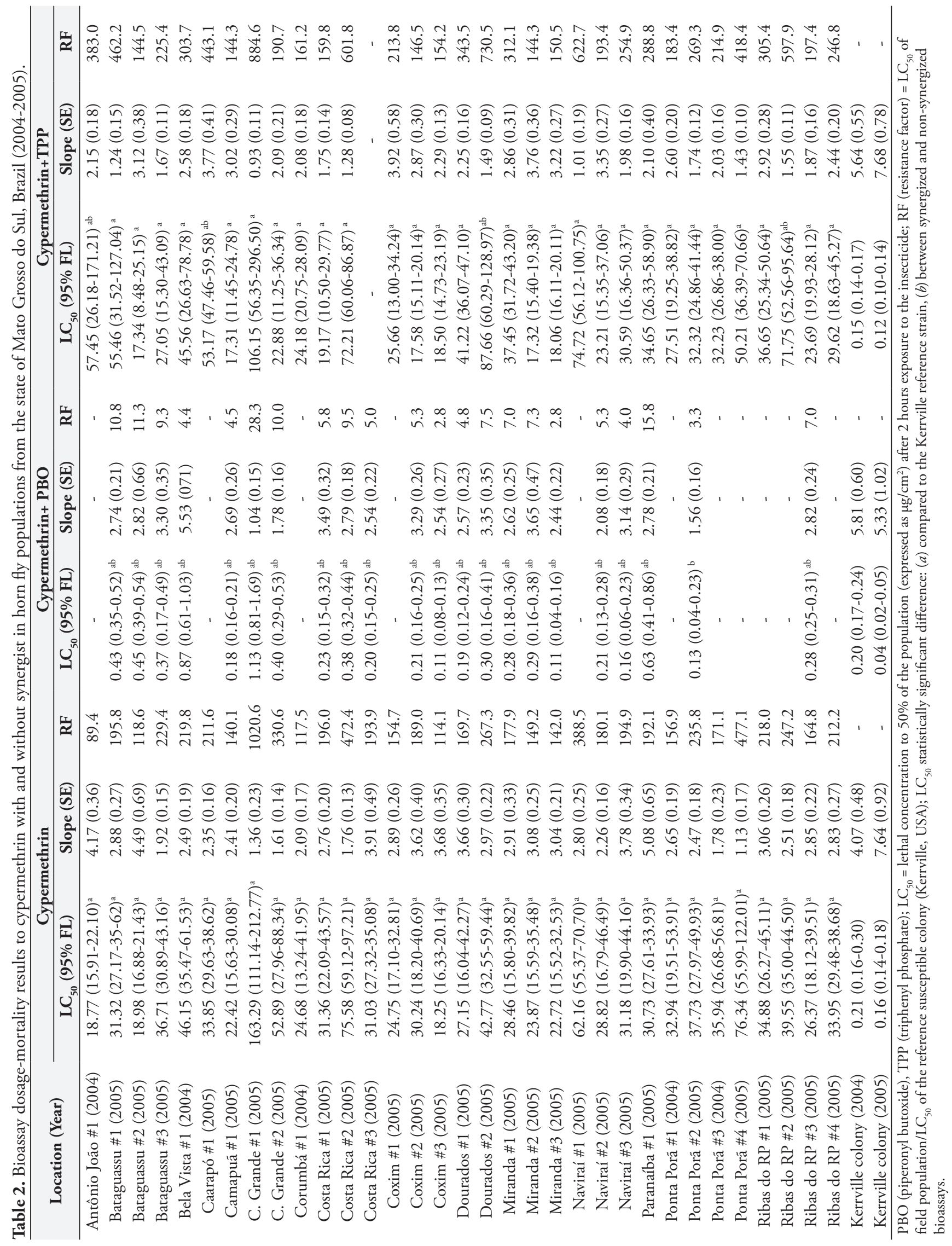


The widespread resistance of horn flies to cypermethrin found in this survey confirmed previous reports from the state (BARROS et al., 2007) and all over the country (BARROS et al., 2012). Previous cypermethrin RFs detected by Barros et al. (2007) did not exceed 91.3 (most below 60), while in the present study the lowest RF was 89.4 and most were above 140 , suggesting that pyrethroid resistance is getting worse in the region. In practice, development of resistance tends to increase insecticide use by producers, by either applying higher amounts of insecticide products and/or reducing the interval between treatments, in an attempt to recover original control levels. As a cyclical process, higher exposure to insecticides tends to increase resistance selection reducing product efficacy and consequently control efficiency, which leads to more insecticide use and higher selection pressure.

The $k d r$ mutation, associated with pyrethroid target site insensitivity, was detected in most horn fly populations, confirming previous reports from the state (GUERRERO; BARROS, 2006) and elsewhere in the country (SABATINI et al., 2009). Horn flies with $k d r$ genotypes were detected in $75 \%$ of sampled populations (Table 3), a higher frequency than previously recorded in the state, which strengthens the apparent worsening trend of pyrethroid resistance in the region. Homozygous (RR) $k d r$ flies were detected only in two populations, the ones with the highest frequencies of mutant flies, similarly as found by Guerrero and Barros (2006).

Although $k d r$ was commonly found within populations, the frequency of mutant flies in each population did not exceed $20 \%$ (allelic frequency $\leq 10 \%$ ) in $83.33 \%$ of the populations (Table 3). Such low frequencies followed a similar trend to that previously reported in the state (GUERRERO; BARROS, 2006; SABATINI et al., 2009) and likely reflected a low to moderate selection pressure associated with routinely poor control practices in most cases. The highest frequency of $k d r$ flies (54.3\%; allelic frequency $=34.3 \%$ ) was detected in the top resistant population
$(\mathrm{RF}=1,020.6)$, which seems compatible with the high potential of resistance known for this mechanism (OPPENOORTH, 1985). However, inhibition of metabolic mechanisms by PBO dropped that RF to only 28.3, which would be the level of resistance actually attributable to $k d r$ in that particular population.

The presence of $k d r$ in most populations suggested a significant role played by this mechanism in pyrethroid resistance in the region; however, its absence in some populations as well as its low frequency in most populations cannot account for the high resistance levels found. Actually, the evidences gathered by previous studies (GUERRERO; BARROS, 2006; BARROS et al., 2007; SABATINI et al., 2009) have already suggested that the major mechanism behind pyrethroid resistance in the country would be metabolic, most likely oxidative. This situation contrasted with findings abroad, where higher frequencies of $k d r$ have been reported and this mechanism seemed to play a more important role (JAMROZ et al., 1998; LI et al., 2003; OYARZÚN et al., 2011).

No toxicity by $5 \%$ TPP was observed to colonized or wild horn flies. Exposure of horn flies to TPP in bioassays did not result in significant reduction of cypermethrin $\mathrm{LC}_{50}$ (Table 2). Increases of cypermethrin susceptibility due to esterase (EST) inhibition by TPP did not exceed 2.3-fold in field populations compared to 1.4-fold for susceptible flies from the reference colony. Guerrero and Barros (2006) failed to detect an esterase-mediated mechanism by using PCR-based assays, but found a significant reduction of cypermethrin $\mathrm{LC}_{50}$ in a single population (with $50 \%$ of $k d r$ flies) in TPP-synergized bioassays, suggesting the involvement of EST as a mechanism of resistance. However, the effect of a synergist that inhibits a detoxication pathway tends to be much greater in the presence of $k d r$, which increases opportunity for insecticide degradation (OPPENOORTH, 1985). Thus, it seems that the actual existence of an EST-based resistance mechanism in Brazilian horn fly populations needs further evidence.

Table 3. Profile of knockdown resistance $(k d r)$ genotype in horn fly populations from Mato Grosso do Sul state, Brazil (2004-2005).

\begin{tabular}{|c|c|c|c|c|c|c|c|}
\hline \multirow{2}{*}{ Location } & \multirow{2}{*}{ Sample size (n) } & \multicolumn{3}{|c|}{$K d r$ genotype $^{1}$} & \multirow{2}{*}{$\begin{array}{l}K d r \text { allelic } \\
\text { frequency }^{2}\end{array}$} & \multirow{2}{*}{$\begin{array}{c}\text { Frequency of } k d r \\
\text { flies }^{3}\end{array}$} & \multirow{2}{*}{ Cypermethrin $\mathrm{RF}^{4}$} \\
\hline & & SS & SR & $\mathbf{R R}$ & & & \\
\hline Antônio João \#1 & 35 & 35 & 0 & 0 & 0.0 & 0.0 & 89.4 \\
\hline Bataguassu \#1 & 35 & 25 & 5 & 5 & 21.4 & 28.6 & 195.8 \\
\hline Bela Vista \#1 & 35 & 32 & 3 & 0 & 4.3 & 8.6 & 219.8 \\
\hline Camapuã \#1 & 35 & 30 & 5 & 0 & 7.1 & 14.3 & 140.1 \\
\hline C. Grande \#1 & 35 & 16 & 14 & 5 & 34.3 & 54.3 & 1020.6 \\
\hline Corumbá \#1 & 35 & 28 & 7 & 0 & 10.0 & 20.0 & 117.5 \\
\hline Costa Rica \#2 & 35 & 32 & 3 & 0 & 4.3 & 8.6 & 472.4 \\
\hline Coxim \#2 & 35 & 35 & 0 & 0 & 0.0 & 0.0 & 189.0 \\
\hline Dourados \#1 & 35 & 35 & 0 & 0 & 0.0 & 0.0 & 169.7 \\
\hline Miranda \#2 & 35 & 34 & 1 & 0 & 1.4 & 2.9 & 149.2 \\
\hline Naviraí \#2 & 35 & 32 & 3 & 0 & 4.3 & 8.6 & 180.1 \\
\hline Paranaíba \#1 & 35 & 35 & 0 & 0 & 0.0 & 0.0 & 192.1 \\
\hline Ponta Porã \#1 & 35 & 33 & 2 & 0 & 2.9 & 5.7 & 156.9 \\
\hline Ponta Porã \#2 & 35 & 34 & 1 & 0 & 1.4 & 2.9 & 235.8 \\
\hline Ponta Porã \#3 & 35 & 31 & 4 & 0 & 5.7 & 11.4 & 171.1 \\
\hline Ribas do RP \#3 & 35 & 34 & 1 & 0 & 1.4 & 2.9 & 164.8 \\
\hline Total & 560 & 501 & 49 & 10 & Avg. 6.2 & 10.5 & - \\
\hline
\end{tabular}


The PBO activity as an inhibitor of microsomal oxidases is well established (CASIDA, 1970; FARNHAM, 1998), being considered as an efficient insecticide synergist and an important tool in studies regarding insecticide metabolism and resistance mechanisms (HODGSON; LEVI, 1998).

No toxicity by $5 \%$ PBO was evidenced to both colonized and wild horn flies. Addition of PBO in bioassays dramatically reduced cypermethrin $\mathrm{LC}_{50} \mathrm{~s}$ in all field populations, dropping cypermethrin RFs (between 114.1 and 1,020.6 in non-synergized bioassays) to 10 or less in $81.82 \%$ of the populations (Table 2). Synergism ratios exceeded 40 (ranged 42.2 to 290.2) in all field populations, while a maximum reduction of 4-fold was observed in $\mathrm{LC}_{50}$ of colonized susceptible flies. Such a sharp fall in cypermethrin RF following $\mathrm{PBO}$ exposure indicated the strong involvement of P450 mono-oxygenases in pyrethroid resistance in all studied horn fly populations. A similar effect of $\mathrm{PBO}$, primarily associated with an enhanced metabolic detoxification by oxidases, has been also observed in highly permethrin resistant house flies, despite the presence of other mechanisms (SCOTT; GEORGHIOU, 1986). Although $k d r$ was detected in more than half of the flies of the top resistant population in the present study, the $\mathrm{LC}_{50}$ was reduced above 140 -fold (from 163.29 to only $1.13 \mu \mathrm{g} / \mathrm{cm}^{2}$ ) following $\mathrm{PBO}$ exposure, confirming that a major mechanism of resistance was oxidative.

Although 5\% PBO showed a high synergism, later unpublished studies indicated that lower $\mathrm{PBO}$ concentrations provided higher synergism to cypermethrin in impregnated paper bioassays, suggesting that the synergism factors reported here would be probably higher if a lower PBO concentration had been used in this study.

Besides inhibition of oxidases, PBO may interfere with other insecticide-insect processes such as the cuticular penetration of insecticides (SCOTT; GEORGHIOU, 1986). However, changes in penetration just provide lower levels of resistance, being of secondary importance (OPPENOORTH, 1985), and would not explain the observed resistance levels. In addition, a partial inhibition of resistance-associated EST by PBO has been observed in some insects (GUNNING et al., 1998; YOUNG et al., 2005), but not in horn flies (LI et al., 2007). Although it should not be discounted that the higher susceptibility of horn flies to cypermethrin following PBO exposure may not rely solely on the inhibition of metabolic oxidation, there was no evidence that other resistance mechanism affected by this synergist played a significant role in the pyrethroid resistance showed by those populations. As mentioned earlier, the presence of $k d r$ may increase the synergist effect, which is also true for PBO; however, the low frequency of this mechanism in almost all analyzed populations surely reduced the $k d r$ importance as a synergist enhancer in this study.

The marked decline in resistance levels of all populations exposed to $\mathrm{PBO}$, the lack of significant increase of susceptibility due to TPP, as well as the absence or low frequency of $k d r$ in highly resistant populations to cypermethrin, all together pointed to the conclusion that the primary mechanism of horn fly resistance to pyrethroids in the studied populations was an enhanced oxidative metabolism by $\mathrm{P} 450$ mono-oxygenases.

Moreover, it should be pointed out that the $\mathrm{LC}_{50} \mathrm{~s}$ obtained from $\mathrm{PBO}$-synergized bioassays were significantly higher than the susceptible colony (even in populations without detected $k d r$ ), which may be explained by incomplete inhibition of oxidases associated with the pyrethroid resistance, presence of $k d r$ (detected or not), and/or involvement of other (undetected) mechanism of resistance.

Pyrethroid resistance levels and mechanisms detected in this study ultimately resulted from the local strategies for controlling horn flies on pastured beef cattle, which routinely rely on the inadequate use of insecticide products applied by backpack sprayers and application of product doses well below the technically recommended (BARROS et al., 2007). Although the selection pressure imposed by this common practice has obviously succeeded for selecting the metabolic mechanism, it seemed to be less successful regarding selection of the $k d r$ mechanism and its associated fitness disadvantages (SCOTT et al., 1997; YOUNGER, 2011). Nevertheless, the importance of $k d r$ may increase quickly if intensity of selection pressure by pyrethroid-dependent control strategies, using more frequent treatments or long lasting formulations, becomes strong enough to overcome the fitness disadvantages showed by $k d r$ flies in the absence of pyrethroids.

As a short-term approach, the use of $\mathrm{PBO}$ tends to increase pyrethroid toxicity against horn flies, thus improving efficacy of pyrethroid products and extending their use in the field for horn fly control. On the other hand, the multiple resistance mechanisms found in most populations makes efficient fly control and resistance management more complex and difficult to achieve if management strategies focus on a single mechanism, such as the use of synergized insecticides.

A worse scenario regarding horn fly resistance to pyrethroids should be expected if pyrethroid products continue to dominate the market and their indiscriminate use persists in the field. Therefore, adequate horn fly control depends not just on reducing pyrethroid use itself, or simply replacing it by an insecticide from another class, but also on developing and adopting alternative control approaches that reduce chemical dependence and improve control efficiency and sustainability.

\section{Acknowledgements}

We thank the ranch owners for allowing the study execution and Ernande Ravaglia and Wibert de Avellar for assistance with field bioassays. We are also grateful to FUNDECT (Foundation for Supporting Development of Education, Science and Technology of the State of Mato Grosso do Sul, Brazil), FAPESP (São Paulo Research Foundation, Brazil), and EMBRAPA (Brazilian Agricultural Research Corporation) for financial support; to Minerthal for providing technical insecticide; and to Felix Guerrero and Andrew Li (USDA-ARS, Kerrville, USA) for bioassays with the susceptible flies.

\section{References}

Barros ATM, Gomes A, Koller WW. Insecticide susceptibility of horn flies, Haematobia irritans (Diptera: Muscidae), in the state of Mato Grosso do Sul, Brazil. Rev Bras Parasitol Vet 2007; 16(3): 145-151. PMid:18078601. http://dx.doi.org/10.1590/S1984-29612007000300006

Barros ATM, Saueressig TM, Gomes A, Koller WW, Furlong J, Girāo ES, et al. Susceptibility of the horn fly, Haematobia irritans irritans (Diptera: Muscidae), to insecticides in Brazil. Rev Bras Parasitol 
Vet 2012; 21(2): 125-132. PMid:22832752. http://dx.doi.org/10.1590/ S1984-29612012000200010

Bull DL, Harris RL, Pryor NW. The contribution of metabolism to pyrethroid and DDT resistance in the horn fly (Diptera: Muscidae). $J$ Econ Entomol 1988; 81(2): 449-458. PMid:3372852.

Carballo M, Martínez M. Hallazgo de Haematobia irritans en Uruguay. Veterinaria (Uruguay) 1991; 27(112): 20-21.

Casida JE. Mixed-function oxidase involvement in the biochemistry of insecticide synergists. J Agric Food Chem 1970; 18(5): 753-772. PMid:4919838. http://dx.doi.org/10.1021/jf60171a013

Farnham AW. The mode of action of piperonyl butoxide with reference to studying pesticide resistance. In: Jones DG. Piperonyl butoxide the insecticide synergist. London: Academic Press; 1998. p. 199-213.

Grisi L, Scott FB. Susceptibilidade de populaçóes da mosca-dos-chifres (Haematobia irritans) a inseticidas no Estado de São Paulo. A Hora Vet 1992; 65: 11-12.

Guerrero FD, Barros T. Role of kdr and esterase-mediated metabolism in pyrethroid-resistant populations of Haematobia irritans irritans (Diptera: Muscidae) in Brazil. J Med Entomol 2006; 43(5): 896-901. http://dx.doi. org/10.1603/0022-2585(2006)43[896:ROKAEM]2.0.CO;2

Guerrero FD, Kunz SE, Kammlah D. Screening of Haematobia irritans irritans (Diptera: Muscidae) populations for pyrethroid resistance-associated sodium channel gene mutations by using a polymerase chain reaction assay. J Med Entomol 1998; 35(5): 710-715. PMid:9775598.

Guerrero FD, Jamroz RC, Kammlah D, Kunz SE. Toxicological and molecular characterization of pyrethroid-resistant horn flies, Haematobia irritans: identification of $\mathrm{kdr}$ and super-kdr point mutations. Insect Biochem Mol Biol 1997; 27(8-9):745-755. http://dx.doi.org/10.1016/ S0965-1748(97)00057-X

Guglielmone AA, Kunz SE, Volpogni MM, Anziani OS, Flores SG. Diagnóstico de poblaciones de la Haematobia irritans (Diptera: Muscidade) resistentes a la cipermetrina en Santa Fe, Argentina. Rev Med Vet (Buenos Aires) 1998; 79: 353-356.

Gunning RV, Moores GD, Devonshire AL. Inhibition of resistance-related esterases by piperonyl butoxide in Helicoverpa armigera (Lepidoptera: Noctuidae) and Aphis gossypii (Hemiptera: Aphididae). In: Jones DG. Piperonyl butoxide the insecticide synergist. London: Academic Press; 1998. p. 215-226.

Hodgson E, Levi PE. Interactions of piperonyl butoxide with cytochrome P450. In: Jones DG. Piperonyl butoxide the insecticide synergist. London: Academic Press; 1998. p. 41-53.

Jamroz RC, Guerrero FD, Kammlah DM, Kunz SE. Role of the $k d r$ and super- $k d r$ sodium channel mutations in pyrethroid resistance: correlation of allelic frequency to resistance level in wild and laboratory populations of horn flies (Haematobia irritans). Insect Biochem Mol Biol 1998; 28(12): 1031-1037. http://dx.doi.org/10.1016/ S0965-1748(98)00094-0

Leora Software. POLO-PC a User's Guide to Probit or Logit Analysis. Berkeley: LeOra Software; 1987.

Li AY, Guerrero FD, Almazán Garcia C, George JE. Survey of resistance to permethrin and diazinon and the use of a multiplex polymerase chain reaction assay to detect resistance alleles in the horn fly, Haematobia irritans irritans (L.). J Med Entomol 2003; 40(6): 942-949. PMid:14765674. http://dx.doi.org/10.1603/0022-2585-40.6.942

Li AY, Guerrero FD, Pruett JH. Involvement of esterases in diazinon resistance and biphasic effects of piperonyl butoxide on diazinon toxicity to Haematobia irritans irritans (Diptera: Muscidae). Pestic
Biochem Physiol 2007; 87: 147-155. http://dx.doi.org/10.1016/j. pestbp.2006.07.004

Luzuriaga R, Eddi C, Caracostantogolo J, Botto E, Pereira J. Diagnóstico de parasitación con Haematobia irritans (L.) en bovinos de Misiones, República Argentina. Rev Med Vet (Buenos Aires) 1991; 72: 262-263.

Moreira-Ferro CK, Daffre S, James AA, Marinotti O. A lysozyme in the salivary glands of the malaria vector Anopheles darlingi. Insect Mol Biol 1998; 7(3): 257-264. PMid:9662475. http://dx.doi.org/10.1111/ j.1365-2583.1998.00067.x

Oppenoorth FJ. Biochemistry and genetics of insecticide resistance. In: Kerkut GA, Gilbert LI. Comprehensive Insect Physiology and Pharmacology, 12. Oxford: Pergamon; 1985. p. 731-773.

Oyarzún MP, Li AY, Figueroa CC. High levels of insecticide resistance in introduced horn fly (Diptera: Muscidae) populations and implications for management. J Econ Entomol 2011; 104(1): 258-265. PMid:21404866. http://dx.doi.org/10.1603/EC10188

Pereira MC, Cossi Junior O, Dias AMS. Efficacy of some insecticides for control of the horn fly. Braz J Vet Res Anim Sci 1994; 31(3-4): 186-190.

Sabatini GA, Ribolla PEM, Barros ATM, Guerrero FD, Schumaker TTS. Knockdown resistance in pyrethroid-resistant horn fly (Diptera: Muscidae) populations in Brazil. Rev Bras Parasitol Vet 2009; 18(3): 8-14. PMid:19772769. http://dx.doi.org/10.4322/rbpv.01803002

Scott FB, Coumendouros K, Grisi L. Avaliação in vitro da susceptibilidade da Haematobia irritans a alguns inseticidas no Estado de Sáo Paulo. Rev Bras Parasitol Vet 1994; 3(2): 83-85.

Scott JA, Plapp Junior FW, Bay DE. Pyrethroid resistance associated with decreased biotic fitness in horn flies (Diptera: Muscidae). Southwest Entomol 1997; 22(4): 405-410.

Scott JG, Georghiou GP. Mechanisms responsible for high levels of permethrin resistance in the house fly. Pestic Sci 1986; 17(3): 195-206. http://dx.doi.org/10.1002/ps.2780170302

Sheppard DC. Oxidative metabolic resistance to cyanopyrethroids in the horn fly (Diptera: Muscidae). J Econ Entomol 1995; 88(6): 1531-1535.

Sheppard DC, Hinkle NC. A field procedure using disposable materials to evaluate horn fly insecticide resistance. J Agric Entomol 1987; 4(1): 87-89.

Slingerland MV. The horn fly. Agric Exp Stat Bull 1891; 37: 378-381. [cited 2012 Nov. 05]. Available from: http://archive.org/stream/ hornflyhaematob00slingoog\#page/n26/mode/2up.

Sparks TC, Quisenberry SS, Lockwood JA, Byford RL, Roush RT. Insecticide resistance in the horn fly, Haematobia irritans. J Agric Entomol 1985; 2(3): 217-233.

Sparks TC, Byford RL, Craig ME, Crosby BL, McKenzie C. Permethrin metabolism in pyrethroid-resistant adults of the horn fly (Muscidae: Diptera). J Econ Entomol 1990; 83(3): 662-665. PMid:2376635.

Valério JR, Guimarães JH. Sobre a ocorrência de uma nova praga, Haematobia irritans (L.) (Diptera, Muscidae), no Brasil. Rev Bras Zool 1983; 1(4): 417-418.

Young SJ, Gunning RV, Moores GD. The effect of piperonyl butoxide on pyrethroid-resistance-associated esterases in Helicoverpa armigera (Hübner) (Lepidoptera: Noctuidae). Pest Manag Sci 2005; 61(4): 397-401. PMid:15605351. http://dx.doi.org/10.1002/ps.996

Younger C. A study of horn fly, Haematobia irritans (L.) (Diptera: Muscidae), target- site sensitivity, susceptibility, and resistance management at selected sites in Louisiana [Dissertation]. Baton Rouge: Louisiana State University and Agricultural and Mechanical College; 2011. [cited 2012 Nov. 05]. Available from: http://etd.lsu.edu/docs/available/ etd-06082011-090019 